\title{
ADAPTASI METODE PEMBELAJARAN MELALUI E-LEARNING UNTUK MENGHADAPI ERA NEW NORMAL
}

\author{
Sri Nuryatin
}

Program Studi Pendidikan IPS, FKIP Universitas Lambung Mangkurat

\author{
srinuryatin676@gmail.com
}

\begin{abstract}
ABSTRAK
Pemerintah telah mengeluarkan kebijakan penerapan new normal pada beberapa sektor termasuk sektor pendidikan. Kondisi ini membuat publik harus beradaptasi dengan keadaan new normal dengan mematuhi aturan yang dibuat pemerintah. Adaptasi ini dimaknai sebagai cara pandang dan perilaku yang baru yang pada akhirnya akan menjadi budaya baru. Perkembangan dunia pendidikan semakin pesat, terlihat dari semakin beragamnya metode pembelajaran yang digunakan, dan pemanfaatan berbagai media yang berguna untuk meningkatkan kualitas hasil pembelajaran. Perkembangan berbagai metode dan media pembelajaran ini seiring dengan adanya kemajuan teknologi yang pesat. Bentuk perkembangan ini yang dapat dimanfaatkan adalah menggunakan e-learning. Penerepan ini digunakan untuk menghadapi era new normal. Penerepan e-learning berimbas pada meningkatnya penggunaan media sosial. Artikel ini menjelaskan bagaimana gambaran adaptasi untuk menghadapi new normal dalam metode pembelajaran e-learning. Aspek yang paling penting adalah penyesuaian pembelajaran pada saat new normal ini.
\end{abstract}

Kata Kunci: E-learning, New Normal, Metode Pembelajaran

\section{PENDAHULUAN}

Berbicara mengenai pendidikan yang tengah menjadi bahan topik pembicaraan dan perdebatan dalam menghadapi new normal. New normal sendiri merupakan istilah yang digunakan dalam berbagai keadaan dan kondisi lain untuk menyiratkan bahwa sesuatu yang tidak biasa atau belum pernah terjadi dan dilakukan sebelumnya telah menjadi biasa. Mengingat pandemi COVID-19 masih melanda Indonesia hingga saat ini.

Respons dunia pendidikan maka menerapkan kebijakan belajar secara online atau daring. Sekolah dan kampus semuanya 'diliburkan' alias beralih menjadi belajar di rumah sebagai konsekuensi kebijakan WFH sehingga social and fisical distancing dapat berjalan untuk mengurangi penyebaran virus (Syaharuddin, 2020).

Memasuki era new normal ini pemerintah memberikan himbauan kepada seluruh masyarakat agar menetapkan protokol kesehatan yang dianjurkan dan mentaati 
aturan yang dibuat. Dunia pendidikan pun terpaksa tetap diliburkan dan diganti dengan sistem pembelajaran daring atau secara online yang berbasis digital.

Metode pembelajaran online secara penuh sudah menjadi pilihan di tengah situasi new normal (tatanan kehidupan baru) saat ini. Metode pembelajaran secara online atau e-learning ini memang bukan hal baru bagi masyarakat Indonesia. New normal pendidikan yang telah kita lakukan membuat kita harus menyesuaikan metode pembelajaran yang sesuai dengan kondisi saat ini dimana berbasis digital, dimana harus mengkombinasikan metode pembelajaran tatap muka di ruang kelas dan e-learning.

Pada pembelajaran daring, pada waktu yang sama guru dan peserta didik berada dalam aplikasi internet yang sama serta berinteraksi satu sama lain layaknya pembelajaran konvensional yang dilakukan selama ini dikelas. New normal pembelajaran secara e-learning merupakan adaptasi dari kondisi dan keadaan yang semua orang terpaksa untuk melakukannya. Meskipun pada kenyataanya, kegiatan belajar mengajar secara e-learning telah dilakukan dari sejak lama oleh beberapa perguruan tinggi, namun sebagai bentuk kesadaran terhadap era revolusi industri 4.0. Dengan menyesuaikan metode pembelajaran melalui e-learning untuk menghadapi new normal maka menjadikan diri sebagai manusia pembelajar, yang mana merupakan satu kunci keberhasilan pembelajaran di era pandemi karena kita harus banyak belajar tentang teknologi informasi.

Salah satu tantangan pendidikan saat ini adalah melakukan penyesuaian di era new normal yang mana belum bisa bertatap muka secara langsung. Maka salah satu solusi yang ditawarkan adalah melakukan proses pembelajaran mandiri atau pembelajaran jarak jauh dengan metode pembelajaran yang dikenal dengan e-learning. Tulisan ini memberikan gambaran dasar bagaimana adaptasi metode pembelajaran elearning untuk menghadapi era new normal.

\section{PEMBAHASAN}

Dalam pemahaman umum sistem pendidikan adalah jumlah keseluruhan dari bagian-bagiannya bekerjasama untuk mencapai hasil diharapkan berdasarkan atas kebutuhan yang ditentukan. Setiap sistem pasti mempunyai tujuan, dan semua kegiatan dari semua komponen atau bagian-bagiannya adalah diarahkan untuk tercapainya tujuan tersebut (Mutiani, M., Subiyakto, B., Jumriani, J., Aslamiah, A., \& Afrina, A., 2019). 
Proses kegiatan belajar mengajar yang awalnya sistem tatap muka langsung diberhentikan dan mengganti proses pembelajaran dengan sistem pembelajaran daring atau e-learning. Pembelajaran dengan metode e-learning yang keseluruhannya memanfaatkan teknologi dalam pembelajaran melalui fasilitas internet sehingga tidak diperlukan tatap muka. Diharapkan meski pembelajarann melalui moda daring atau elearning tetap mencapai keberhasilan pembelajaran.

Keberhasilan pembelajaran ditentukan dari berbagai komponen yang saling berinteraksi. Komponen pembelajaran, di antaranya dosen, mahasiswa tujuan, materi, metode, dan strategi pembelajaran. Undang-undang Nomor 14 Tahun 2005 tentang Guru dan Dosen bahwa kompetensi pedagogik adalah "kemampuan mengelola pembelajaran mahasiswa". Kompetensi pedagogik merupakan jenis kompetensi yang perlu dikuasai dosen. Kemampuan tersebut terlihat dari pengelolaan pembelajaran meliputi; pemahaman karakteristik mahasiswa, perencanaan dan pelaksanaan, evaluasi, dan pengembangan berbagai potensi mahasiswa (Rahman, A. M., Mutiani, M., \& Putra, M. A. H, 2019). Hal ini berarti seorang guru harus mengelola pembelajaran dengan maksimal meskipun dalam kondisi apapun, baik itu pembelajaran tatap muka langsung maupun melalui moda daring.

Pembelajaran memiliki beberapa komponen penting didalamnya yang saling menunjang satu sama lain. Sata komponen yang dimaksud disini adalah metode pembelajaran. Metode berasal dari Bahasa Inggris yakni method dan Bahasa Yunani methodos. Methodos berarti sesudah atau melampaui, dan hodos berarti cara atau jalan. Secara istilah, metode dipergunakan untuk mencapai tujuan yang telah ditetapkan (Syaharuddin, S., \& Mutiani, M., 2019) .

Metode merupakan cara yang dimanfaatkan guru mengimplementasikan rencana pembelajaran yang telah disusun dan merupakan alat untuk mencapai tujuan pembelajaran. Metode pembelajaran merupakan satu komponen pembelajaran yang harus digunakan dalam kegiatan pembelajaran. Penggunaan metode mengajar harus dapat menciptakan terjadinya interaksi antar peserta didik maupun antara siswa dengan guru sehingga proses pembelajaran dapat dilakukan secara maksimal. Dalam menentukan metode pembelajaran guru hendaknya tidak asal pakai. Metode yang dipilih dalam pembelajaran memperhatikan ketepatan (efektivitas) (Syaharuddin, S., \& Mutiani, M., 2019). Maka dalam kondisi new normal ini guru harus menggunakan metode yang sesuai dan lebih memungkinkan digunakan pada pembelajaran moda daring ini. 
E-learning merupakan sistem pembelajaran yang menggunakan perangkat elektronik sebagai media pembelajarannya. E-learning sendiri merupakan pembelajaran berbasis web yang bisa diakses dari internet. Dari pendapat diatas dapat disimpulkan bahwa e-learning merupakan pembelajaran berbasis teknologi internet untuk memudahkan seseorang menerima pengetahuan dan meningkatkan keterampilan peserta didik maupun mahasiswa.

New normal adalah kebijakan membuka kembali aktivitas dan kegiatan publik secara terbatas dengan menggunakan standar kesehatan yng sebelumnya tidak ada, sebelum pandemi. New normal merupakan tahapan baru setelah kebijakan pembatasan sosial yang diberlakukan untuk mencegah penyebaran wabah virus Covid 19.

Budaya berkembang seiring dengan adaptasi dengan kondisi geografisnya untuk menghadirkan yang hebat pengaruh yang unik bagi kehidupan manusia (Syaharuddin, S., Susanto, H., \& Putra, M. A. H., 2020). New normal ini sendiri kan adalah tatanan baru yang artinya juga merupakan budaya baru pada saat penyebaran wabah virus Covid 19. Setiap daerah mempunyai cara berbeda dalam proses adaptasi pada saat new normal, terutama dalam sektor pendidikan.

Pada saat new normal dalam sektor pendidikan juga perlu penyesuaian pola pembelajaran yang sesuai dengan kondisi saat ini. Penyesuaian metode pembelajaran melalui e-learning untuk menghadapi new normal ini bisa dilakukan dengan tetap menggunakan sumber belajar yang sesuai dan bisa diaplikasikan dalam e-learning. Ambariah (dalam Ajidayanti, A., \& Abbas, E. W., 2019) menyatakan bahwa sumber studi sosial itu dapat bervariasi. Sumber studi sosial dapat menggunakan buku sumber belajar, Internet, majalah, koran, dan lingkungan. Meskipun tidak melakukan pembelajaran tatap muka langsung, sumber belajar yang digunakan dalam metode elearning bermacam-macam. Dalam Putro, H. P. N., \& Jumriani, J. (2020) dijelaskan bahwa pada pembelajaran IPS, buku merupakan satu-satunya sumber belajar yang digunakan pada proses pembelajaran. Itu berarti pada saat proses pembelajaran melalui e-learning dapat menjadikan buku bentuk softfile pdf untuk dibagikan kepada peserta didik sebagai bentuk adaptasi metode pembelajaran ini.

Syaharuddin (dalam Abbas, E. W., Handy, M. R. N., Shaleh, R. M., \& Hadi, N. T. F. W., 2020) menyatakan bahwa menggunakan sumber belajar dalam bentuk lingkungan sosial-budaya yang plan (RPP) diyakini membuat pembelajaran lebih bermakna dan bervariasi sehingga tidak membosankan. Itu berarti guru harus membuat pembelajaran bervariasi meskipun menggunakan metode e-learning tapi tidak 
membatasi sumber belajar. Guru harus memutar otak untuk beradaptasi menghadapi new normal ini.

Adaptasi penggunaan metode pembelajaran melalui e-learning dalam menghadapi era new normal ini diharapkan tetap bisa mengajarkan penanaman nilai. Bisa dilakukan dengan meminta peserta didik melihat foto dan video biografi seseorang. Seperti dengan memberikan contoh biografi para pemimpin lokal (dalam Wahyuningsih, S., Abbas, E. W., \& Mutiani, M. :2020).

Metode e-learning diharapkan tidak menganggu sistem pembelajaran dengan tetap melakukan kebiasaan kebiasaan sebelum pandemi, seperti kebiasaan menulis contohnya. Warmansyah Abbas, E. R. S. I. S. (2020) tetap melakukan kebiasaan tanpa melabrak protokol kesehatan, setelah melakukan aktivitas kampus secara daring, kemudian membaca atau menulis lagi. Abbas, E. W. (2020). Menjelaskan dengan membelajarkan diri menulis dan menjadikan menulis sebagai tugas keseharian. Hal ini dapat dilakukan dalam penyesuaian melakukan pembelajaran melalui e-learning dalam menghadapi new normal.

Nilai, budaya, kebiasaan, tradisi dan adat istiadat, dan moral tertentu yang ada di masyarakat perlu diketahui dan dipelajari oleh peserta didik. Mengingat sumber belajar bisa datang dari mana saja buku, internet, dan lingkungan selama itu terkait dengan materi yang diajarkan (Yuniarti, D., Subiyakto, B., \& Putra, M. A. H. :2020). Itu berarti harus tetap diajarkan kepada peserta didik meskipun pembelajaran dilakukan melalui e-learning.

Terkait dengan nilai, nilai itu tidak dapat dilihat dalam bentuk fisik, hal ini dikarenakan nilai adalah harga sesuatu hal yang harus dicari dalam proses manusia menanggapi sikap manusia yang lain. Nilai pada dasarnya sudah ada dan terkandung dalam sesuatu, maka dengan pendidikan membantu seseorang untuk dapat menyadari dengan mencari nilai-nilai mendalam dan memahami kaitannya satu sama lain serta peranan dan kegunaan bagi kehidupan (Subiyakto, B., \& Mutiani, M., 2019). Hal ini memberi pemahaman bahwa pendidikan sangat penting, meskipun dalam keadaan dan kondisi apapun seperti kondisi saat ini pembelajaran hanya melalui e-learning, namun hal ini tidak mempengaruhi proses belajar, karena sudah banyak metode dan media pembelajaran melalui moda daring.

Pendidikan adalah wahana bagi siswa untuk mengenali dan mengembangkan potensi mereka. Melalui pendidikan, peserta didik belajar dan mencari pengetahuan yang mengakumulasi kekayaan intelektual. Siswa yang membekali diri dengan 
kecerdasan juga harus peka dan mampu menghadapi sosial masalah di sekitar mereka (Jamaluddin, J., Syaharuddin, S., \& Putra, M. A. H. :2020). Itu berarti peserta didik harus peka dan mampu menghadapi kendala yang terjadi selama pembelajaran daring melalui e-learning ini.

Pendidikan sendiri modal utama yang harus dimiliki oleh setiap individu. Dan terkadang masyarakat sering tidak memperdulikan akan pentingnya program pendidikan, terutama pada kalangan anak remaja sekarang ini banyak ditemukan karena putus sekolah (Hasanah, M., \& Mutiani, M. :2019). Pada saat new normal ini diharapkan masyarakat khususnya para orang tua juga ikut beradaptasi terhadap pembelajaran melalui e-learning, jangan membebankan pekerjaan rumah kepada anak ketika dia sedang melakukan pembelajaran daring.

Proses adaptasi akan berjalan dengan selaras ketika semuanya mendukung proses penyesuaian proses belajar, karena sejatinya metode pembelajaran juga mempengaruhi keberhasilan pencapaian proses belajar mengajar.

\section{SIMPULAN}

Metode pembelajaran merupakan satu dari beberapa komponen pembelajaran yang harus digunakan dalam kegiatan pembelajaran. Perkembangan berbagai metode pembelajaran berjalan seiring dengan pesatnya kemajuan teknologi. Bentuk perkembangan yang dapat dimanfaatkan adalah menggunakan e-learning. E-learning merupakan pembelajaran berbasis teknologi internet yang digunakan untuk memudahkan seseorang dalam menerima pengetahuan serta meningkatkan keterampilan peserta didik maupun mahasiswa.

New normal sendiri adalah istilah kebijakan membuka kembali aktivitas dan kegiatan publik dengan menggunakan standar kesehatan yang sebelumnya tidak ada secara terbatas, sebelum pandemi. Pada saat new normal sektor pendidikan perlu penyesuaian pola pembelajaran yang sesuai dengan kondisi saat ini dengan melakukan penyesuaian terhadap metode pembelajaran e-learning untuk menghadapi new normal. Metode e-learning diharapkan tidak menganggu sistem pembelajaran dengan tetap melakukan kebiasaan kebiasaan sebelum pandemi dengan melakukan penyesuaian terhadap keadaan sekarang. 


\section{DAFTAR PUSTAKA}

Abbas, E. W. (2020). Menulis Artikel Jurnal. Menulis Artikel Jurnal.

Abbas, E. W., Handy, M. R. N., Shaleh, R. M., \& Hadi, N. T. F. W. (2020). Ecotourism of Martapura River Banjarmasin as a Learning Resources on Social Studies. The Innovation of Social Studies Journal, 1(2), 111-119.

Ajidayanti, A., \& Abbas, E. W. (2019). Utilization of Tourism Bekantan Mascot as a Learning Resource On Social Studies. The Innovation of Social Studies Journal, 1(1), 78-86.

Hasanah, M., \& Mutiani, M. (2019). Pemahaman Wajib Belajar 12 Tahun di Sekolah Bawang Banjarmasin. Bubungan Tinggi: Jurnal Pengabdian Masyarakat, 1(1), 15-20.

Jamaluddin, J., Syaharuddin, S., \& Putra, M. A. H. (2020). The Form of Basirih Society Social Interaction in The Dome of Habib Hamid Bin Abbas Al-Bahasyim as a Learning Resource on Social Studies. The Kalimantan Social Studies Journal, 1(2), 159-168.

Mutiani, M., Subiyakto, B., Jumriani, J., Aslamiah, A., \& Afrina, A. (2019). Laporan Penelitian: Relevansi Modal Sosial Dalam Pembelajaran IPS (Studi Kasus Dalam Sistem Zonasi Di Smp Negeri Kota Banjarmasin).

Putro, H. P. N., \& Jumriani, J. (2020). KEHIDUPAN SOSIAL DAN EKONOMI MASYARAKAT BANTARAN SUNGAI A SEBAGAI SUMBER BELAJAR IPS.

Rahman, A. M., Mutiani, M., \& Putra, M. A. H. (2019). Pengaruh kompetensi pedagogik dosen terhadap motivasi belajar mahasiswa pendidikan IPS. Jurnal Darussalam: Jurnal Pendidikan, Komunikasi dan Pemikiran Hukum Islam, 10(2), 375-387.

Subiyakto, B., \& Mutiani, M. (2019). Internalisasi nilai pendidikan melalui aktivitas masyarakat sebagai sumber belajar ilmu pengetahuan sosial. Khazanah: Jurnal Studi Islam dan Humaniora, 17(1), 137-166.

Syaharuddin, S. (2020). PEMBELAJARAN MASA PANDEMI: DARI KONVENSIONAL KE DARING. PEMBELAJARAN MASA PANDEMI: DARI KONVENSIONAL KE DARING.

Syaharuddin, S. (2020). Menimbang Peran Teknologi dan Guru dalam Pembelajaran di Era COVID-19. Menimbang Peran Teknologi dan Guru dalam Pembelajaran di Era COVID-19.

Syaharuddin, S., \& Mutiani, M. (2020). STRATEGI PEMBELAJARAN IPS: Konsep dan Aplikasi.

Syaharuddin, S., Susanto, H., \& Putra, M. A. H. (2020). Portrait of Community Economic Activities in The River as a Learning Resources on Social Studies With Local Culture-Based. The Innovation of Social Studies Journal, 1(2), 178-187.

Wahyuningsih, S., Abbas, E. W., \& Mutiani, M. (2020). Implementation of Leadership Value of Rudy Resnawan as a Learning Resources on Social Studies. The Innovation of Social Studies Journal, 1(2), 169-177. 
WARMANSYAH ABBAS, E. R. S. I. S. (2020). Menulis di Era Covid-19: Memanage Trauma Psikologis Menghindari Psikosomatis. Menulis di Era Covid-19: Memanage Trauma Psikologis Menghindari Psikosomatis.

Yuniarti, D., Subiyakto, B., \& Putra, M. A. H. (2020). Economic Activities in Kuin Floating Market as a Learning Resource on Social Studies. The Kalimantan Social Studies Journal, 1(2), 130-140. 